\title{
The Effective Factors in Abnormal Error of Earnings Forecast-In Case of Iran
}

\author{
Hamid Rasekhi \\ Supreme Audit Curt of Mashhad, Iran \\ Alireza Azarberahman (Corresponding author) \\ Dept. of Accounting, Islamic Azad University-Mashhad, Iran \\ Tel: +98-915-119-1929Ｅ-mail: a_berahman@yahoo.com
}

Jalal Azarberahman

Supreme Audit Curt of Mashhad, Iran

Received: July 3, 2014

Accepted: August 5, 2014 Published: December 1, 2014

doi:10.5296/ajfa.v6i2.5901

URL: http://dx.doi.org/10.5296/ ajfa.v6i2.5901

\begin{abstract}
Purpose: the main purpose of this research is to examine the effective factors in abnormal error of earnings forecast.

Design/methodology/approach: this research is an applied research, and its design is semi-empirical, which is done by the method of post-event (past information). The statistical population of the research includes all companies listed in Tehran Stock Exchange (TSE), and its period is four years, from 2010 to 2013. To examine the hypotheses, correlation analysis, and variance analysis test are used.

Findings: the results of this research indicate there is a meaningful relationship between the type of industry, and the effective factors in abnormal error of earnings forecast. The mining, chemical materials, petrochemical and pharmaceutical industries have high abnormal error of earnings forecast, while metal industries, agriculture, and animal husbandry have low abnormal error of earnings forecast. Also we find in this research that there is a meaningful relation between the firm size, and the firm age in stock exchange. Finally, simultaneous effect of the three factors on abnormal error of earnings forecast was examined.
\end{abstract}

Keywords: Earning per share, Abnormal error of earnings forecast, Firm size, Firm age, Industry type, Forecasted earning per share 


\section{Introduction}

Decision makers need useful and helpful information for making a correct and exact decision. To do so, required financial information should be available for them by financial reports of firms. Most of users emphasize on items they perceive as the most relevant information. Information on earning per share is a scale considered as the most relevant by most users. Direct and indirect observations confirm that reported earning per share and forecasted earning per share have direct effect on the stock market price, and investors want this information.

American Financial Accounting Standards Board (FASB) states that the main purpose of financial reporting for business enterprises is to satisfy the informational needs of external users, i.e., affording the information to people who have not the necessary power to order the firm for their required information, so should use the information that the managers afford for them. The management of business enterprise is bound to provide them with the information such as forecasted earning per share, as an estimation of the firm's future perspective. The correct decision making make the investor to reach his/her expectations from the investing, and the firm can attract the trust of the user by providing the correct information.

The researches indicate that forecasts about the earning per share have information content (Ball \& Brown-1968, Beaver-1968). But if the management does not provide the investors by such information, they should do it themselves, or ask for the help of financial analysts.

The accuracy of earning forecast depends on the type of information resources. The resource which leads to less mistakes, i.e., its forecast is closer to the reality, would be more accurate. Many studies have performed to compare the accuracy of earning forecasts by managers, or by analysts with time series models (Ruland-1978, Emhof-1978). The results indicate that the managers' or analysts' forecasts are more accurate than time series models, but in long term it would be inversed. Doing such researches confirms the importance of the issue.

According to article 5 of Regulations on Disclosure of Information by the Companies Registered in the Tehran Stock Exchange, the firms are bound to publish the earning per share forecast every three months to the public, at most 20 days after the end of three months period.

This research tries to introduce some of the factors may be effective in reducing the error of earning forecasts to the investors in order to help them choose the firms with more accurate earning forecast when buying the stocks of firms.

\subsection{Review of the regulations on earning forecast}

Majority shareholders have access to much information, and even expect to receive the information out of access of minority shareholders. Minority shareholders should be relied on agents.

U.S. Securities and Exchange Commission (SEC) permanently encourages the companies to disclose more information for the welfare of minority shareholders.

In early 1973, the Securities and Exchange Commission announced that for the first time the companies registered in the stock exchange would have the permission to disclose the earning forecasts. The next plan was proposed in 1975. In this plan, the companies were obliged to 
publish the forecasts information along with financial reports. These obligations cause the management information to be almost equal to information the public has. In April 1976 the proposal of the Securities and Exchange Commission war removed for the large resistance. In the lack of earning forecast disclosure by managements, the minority shareholders always rely on the professional analysts.

Tehran Stock Exchange considered as the main and most important center in Iran for capital exchange and established in 1966 is bound to give this information to the organization:

a. The annual audited financial statements and reports, and the summary of annual statement of the agent activity which is confirmed by reliable auditor of the Stock Exchange at most four months after the end of financial year.

b. Any kind of change in announced conditions to the organization for the license.

c. Other documents and information requested by the organization, and all the reports mentioned in the enacted regulations in the context of pertinent rules.

This process continued till 1979, and after that the Stock Exchange was almost suspended. From 1991 to 1996 the monthly statistics for production and sale, sale forecast, annual sale, and the real statistics for production and sale of the previous year were considered as the basis for pricing and the useful information for the investors' decision makings.

In 1997, according to a circular, Tehran Stock Exchange bound the companies to announce also the real quarterly earning per share, and annual estimated earning per share.

In 2000, Tehran Stock Exchange bound the companies to publish the analyzed midterm six-month information in standard forms, because of the importance of midterm financial reports in the users' decision makings for regulating the methods of making reports, and increasing the reliability. It is obvious that presenting information in this framework, the announcement of monthly statistics for production and sale by companies was cancelled. Presenting the information on earning per share forecast was continued.

Paragraph c of article 5 of the Regulations on Disclosure of Information by the Companies Registered in the Tehran Stock Exchange in 2002 bound the companies to publish the earning per share forecast every three months, at most 20 days after the end of three months period.

\section{Research Literature}

2.1 Information content of earning: in 1960s, the accounting researches were directed to positive theories. Positive theories help the explanation of accounting phenomena. Since we need fundamental theories of behavioral or economic sciences to explain and forecast in positive accounting researches, the financial economy theory is a base for actions and reactions in capital market. This branch of research is the base for accounting researches which examine the relation of price and accounting information.

Ball and Brown (1968) were the first ones who used these researches. They examined the relation between annual earnings and annual abnormal return rate, and found that the earnings have information content, i.e. the changes in stock prices for a given period depend on the unexpected earnings of that period. This reflects the presence of different information resources which help the market in earnings forecast. Beaver (1968) in a separate research confirmed the information content of earnings. The results of his study showed that 
announcement of earnings makes abnormal changes in return.

Patell (1976) examined the evaluation of information content of earnings forecast with the impact of announcing forecasted earnings on price of stocks. The sample of Patell included 258 firms among 336 firms for the period of 1963 to 1969. The results of the research reflected the reality that the announcement of forecasts would be followed by modification in stocks prices, so the forecasted earnings have information content.

Jahankhani and Saffarian (2003) studied the information content of estimated earnings. In this research, the price changes of 27 companies were collected in the period of 1995 to 1997. The information on four weeks before and after the announcement of estimated earnings was studied. The results showed that the estimated earnings per share had information content, and made the price and volume of transactions to change in TSE. However, since the announcement of estimated earnings per share is an effective factor in the investors and shareholders' decision makings about buying and selling of shares, the earnings forecast per share should have the minimum deviation from its real value. But unfortunately, for the lack of proper policies in Tehran Stock Exchange, there were large disturbance in forecast figures, especially before 1997.

2.2 Comparison of the accuracy in earnings forecast due the resources present it: Kreg and Malkiel (1968) studied the earnings forecast for 5 investment companies for five years, and concluded that the accuracy of the forecasts of analysts is better than time series models. Richard (1976) collected the analysts' forecasts about earnings per share of 92 companies in New York Stock Exchange during 1972-1976, and classified them in 5 classes due to industry type (banking, construction, chemicals, pharmaceutics, and electronics).

The results showed that the relative error of analysts' forecasts was $24.1 \%$, while relative error of time series models is $38.9 \%$. Therefore, the analysts' forecasts are more accurate. Moreover, the relative error of forecasts was least for banking industry, and most for electronics industry.

Ruland (1978) compared the managers' and analysts' forecasts, and both of them with time series models for four years.

The findings indicated that managers' forecasts were more accurate than analysts'. But the difference is not significance. Moreover, he found that analysts' forecast, if announce before managers', is less accurate compared with when announce after managers' forecasts.

Hamid Khaleghi Moghaddam (1999) studied the accuracy of earnings forecasts announced by managers in 45 firms of Tehran Stock Exchange. In this research, the relation of four variables of share prices, firm size, firm age, and the degree of financial leverage with accuracy of earnings forecast was examined by simple and multi-variable regressions. The results showed that $39 \%$ of the accuracy of earnings forecast was about the changes in share prices, and $44 \%$ of it was about the firm size. It also showed that firm age and degree of financial leverage have no impact on determining accuracy of earnings.

2.3 Accuracy of earnings forecast in primary issue of stocks: Firth (1998) studied the accuracy of earnings forecast in primary issues of shares in Singapore Stock Market. In this research 116 primary issues in Singapore Stock were analyzed between 1977-1992. According to findings, 
there was a positive relation between managers' earnings forecasts and shares evaluation in their primary issue.

Lonkain and Firth (2005) in another study surveyed the accuracy of earnings forecast in primary issues of shares in Thailand Stock Market, and its relation with shares evaluation from 1991 to 1997. The results showed that the forecasts are in an optimistic way, that is the forecasted earnings are more than real earnings. However, the earnings forecasted by managers are more accurate than time series models in a meaningful manner. So, forecasting of earnings in primary issues has information content.

Bahramian (2006) evaluated the accuracy of forecasted earnings per share in the companies were offered their shares for the first time in Tehran Stock Market, and companies increased their capital in Stock Market. The period of this study was 2000-2002, and included 81 companies. Seven variables including firm size, period, firm age, type of activity, degree of financial leverage, the auditor opinion, and macroeconomic conditions were identified in determining accuracy of earnings forecast.

The results showed that the error of earnings forecast has direct relation with the period of forecast, and fluctuations in stock index, and there were no meaningful relation with firm size, firm age, degree of financial leverage, auditor opinion and industry type.

\section{Research Methodology}

\subsection{Research Method, Statistical Population, and Sampling Method}

In this research, we used the correlation type method, and studied the relations between independent and dependent variables by statistical methods such as regression and correlation test. This research is also, considered as post-event (using past data).

The statistical population of this research includes firms were active in Tehran Stock Market from 2010 to 2013. Then, firms were active just in one or two years of this period are included too. To make the data homogenous, firms were selected according to following items:

1. The firms listed in Tehran Stock Exchange have different end dates for their financial years (March 20, June 20, July 21, September 21, October 21, November 20 and December 20). This difference is because of the difference in the activities and production cycles. The homogeneity of sample firms in end date of financial year is important, especially on the time of offering the earnings forecast per share, and their comparison capability. Most firms in Tehran Stock Exchange have the March 20 as their end date of financial year, so we selected these firms.

2. The firms which are member of financial intermediaries, holdings, and banks are firms whose performance is depended on the activities of other firms, and are distinct from other firms clearly. So the accuracy of earnings forecast in these firms is different from other firms. Therefore, we excluded these firms from our study.

3. Several firms have not announced the earnings forecast per share despite the obligation of the Regulations on Disclosure of Information by the Companies listed in the Tehran Stock Exchange, or their earnings forecast are not available. We excluded these firms. Then, the 
sample of our study encompasses the firms had announced their earnings forecast for at least one year in the period of this study.

4. The firms their transactions were completely ceased during the period of this study were excluded.

Considering the limitations mentioned above, the statistical population in 2010, 2011, 2012, and 2013 were respectively 130, 127, 154, and 160. The firms under our research are shown in Table 1, according to industry type.

Table 1. firms according to industry type

\begin{tabular}{llcccc}
\hline TYPE OF INDUSTRY & No. in & No. in & No. in & No. in \\
& $\mathbf{2 0 1 0}$ & $\mathbf{2 0 1 1}$ & $\mathbf{2 0 1 2}$ & $\mathbf{2 0 1 3}$ \\
\hline 1 & Mining and related products & 26 & 31 & 37 & 39 \\
2 & Agriculture, animal husbandry, and related industries & 21 & 14 & 19 & 22 \\
\multirow{2}{*}{3} & $\begin{array}{l}\text { Chemical, petrochemical, and pharmaceutical substances } \\
\text { and related products }\end{array}$ & 38 & 35 & 36 & 37 \\
4 & Machinery, equipments, and electric devices & 35 & 35 & 42 & 42 \\
5 & Basic metals and related products & 10 & 12 & 20 & 20 \\
\hline & Total & 130 & 127 & 154 & 160 \\
\hline
\end{tabular}

\subsection{Hypotheses of the Research}

Studying the literature review, we formulated the following hypotheses:

The first hypothesis:

$H_{0}=$ There is not a meaningful relation between the industry type and abnormal error of earnings forecast.

$H_{0}: P_{0} \neq \mu_{i} \quad \forall_{i, l}$

$H_{1}=$ There is a meaningful relation between the industry type and abnormal error of earnings forecast.

$H_{1}: \mu_{t}=\mu_{j} \quad \forall_{t, j}$

The test statistic for examining the first hypothesis is variance analysis. If the F-value were close to one, it can be concluded that there is no meaningful difference among the average of samples. If there were large difference among the average of samples, the numerator would become larger, and the F-value would be more than one, so there would be a meaningful difference among the averages of samples.

The second hypothesis: 
$H_{0}=$ There is not a meaningful relation between firm size and abnormal error of earnings forecast.

$H_{0}: \mu \neq 0$

$H_{1}=$ There is a meaningful relation between firm size and abnormal error of earnings forecast.

$H_{1}: \rho=0$

The third hypothesis:

$H_{0}=$ There is not a meaningful relation between firm age and abnormal error of earnings forecast.

$H_{0}: \rho \neq 0$

$H_{1}=$ There is a meaningful relation between firm age and abnormal error of earnings forecast.

$H_{1}: \rho=0$

The statistic test for examining the second and third hypotheses is employing t distribution (t-student) with the degree of freedom of $n-2$. Since the purpose of this research is to study the distribution of the characteristics of statistical population, the employed research method is descriptive longitudinal survey. In longitudinal surveys, data are collected during the time, or in other words, in different times, so we can find the changes due time, and the relations of variables through the time. After collecting data, we used the variance analysis test, and t test, in the confidence level of 95\% (significance level of 5\%). The statistic level acquired would confirm or reject the relations between independent and dependent variables by confirming or rejecting the hypotheses.

\subsection{Variables of Research}

Independent variables of this research are: (1) Firm age, (2) Industry type, (3) Firm size. To evaluate the firm age variable, we considered the time the firm has been accepted in TSE. Then, the firms were divided into three groups: (a) firms with the age of less than 5 years, (b) firms with the age of 5-10 years, and (c) firms with the age of more than 10 years.

The firms were selected among (a) Mining and related products, (b) Agriculture, animal husbandry, and related industries, (c) Chemical, petrochemical, and pharmaceutical substances and related products, (d) Machinery, equipments, and electric devices, and (e) Basic metals and related products. The firm size variable was also measured according to net sales of firms. 


\section{Macrothink}

Asian Journal of Finance \& Accounting

ISSN 1946-052X

2014, Vol. 6, No. 2

The dependant variable is abnormal error of earnings forecast, which is obtained due the following:

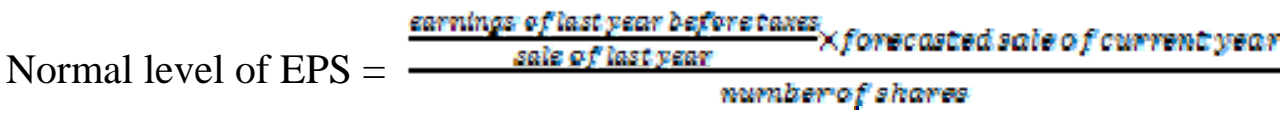

Abnormal error of earnings forecast $=$ forecasted EPS - normal EPS

\section{Results of Testing the Research Hypotheses}

Examining the first hypothesis:

For examining the first hypothesis, we used the variance test to indicate the difference in the extent of abnormal error of earnings forecast among different industries, and single averages comparison test for comparing industries. These analyses are shown in figures 2 and 3.

Table 2. variance analysis

\begin{tabular}{lccccc}
\hline Source & sum of squares & f.d & deviations average & F-value & P-value \\
\hline Among groups & 26.42 & 4 & 6.61 & 3.52 & 0.008 \\
Within groups & 31.1062 & 566 & 1.88 & & \\
Total & 1088.73 & 570 & & & \\
\hline
\end{tabular}

For doing variance analysis test, first the data were normalized. To normalize the data, we used the fourth root. As shown in above table, according to probability value and level of test, it can be stated that the null hypothesis, i.e., there is not meaningful relation between the type of industry and the extent of abnormal error of earnings forecast would be rejected. In other words, it can be stated with the probability of 95\% that there is a meaningful relation between the type of industry and the extent of abnormal error of earnings forecast. 
Table 3. single averages test

\begin{tabular}{|c|c|c|c|c|c|}
\hline & $\begin{array}{c}\text { Mining and } \\
\text { related } \\
\text { products } \\
\end{array}$ & $\begin{array}{l}\text { Agriculture, } \\
\text { animal } \\
\text { husbandry, and } \\
\text { related } \\
\text { industries } \\
\end{array}$ & $\begin{array}{c}\text { Chemical, } \\
\text { petrochemical, and } \\
\text { pharmaceutical } \\
\text { substances and } \\
\text { related products }\end{array}$ & $\begin{array}{c}\text { Machinery, } \\
\text { equipments, } \\
\text { and electric } \\
\text { devices }\end{array}$ & $\begin{array}{c}\text { Basic metals } \\
\text { and related } \\
\text { products } \\
\end{array}$ \\
\hline $\begin{array}{l}\text { Mining and related } \\
\text { products }\end{array}$ & & 0.010 & 0.852 & 0.024 & 0.016 \\
\hline $\begin{array}{l}\text { Agriculture, } \\
\text { animal husbandry, } \\
\text { and related } \\
\text { industries }\end{array}$ & 0.010 & & 0.014 & 0.460 & 0.998 \\
\hline $\begin{array}{l}\text { Chemical, } \\
\text { petrochemical, and } \\
\text { pharmaceutical } \\
\text { substances and } \\
\text { related products }\end{array}$ & 0.852 & 0.014 & & 0.034 & 0.022 \\
\hline $\begin{array}{l}\text { Machinery, } \\
\text { equipments, and } \\
\text { electric devices }\end{array}$ & 0.024 & 0.460 & 0.034 & & 0.489 \\
\hline $\begin{array}{l}\text { Basic metals and } \\
\text { related products }\end{array}$ & 0.016 & 0.998 & 0.022 & 0.489 & \\
\hline
\end{tabular}

To determine the best industry we used single averages test. As we see in Table 3 , there is a meaningful difference in the $5 \%$ level of significance between some industries. So, we can classify the industries into two categories:

a. The industries with relatively low abnormal error of earnings forecast including: (1) Basic metals and related products, (2) Agriculture, animal husbandry, and related industries, and (3) Machinery, equipments, and electric devices, and

b. The industries with relatively high abnormal error of earnings forecast including: (1) Mining and related products, and (2) Chemical, petrochemical, and pharmaceutical substances and related products.

Examining the second hypothesis:

In examining the second hypothesis, we used Pearson's correlation coefficient test, and simple linear regression after the conversions related to normalization. To normalize the data on abnormal error of earnings forecast, we used the fourth root of the numbers, and to normalize the values of firm size, the best conversion is logarithm. Figures 4 and 5 show the data on abnormal error of earnings forecast and firm size before and after normalization. 

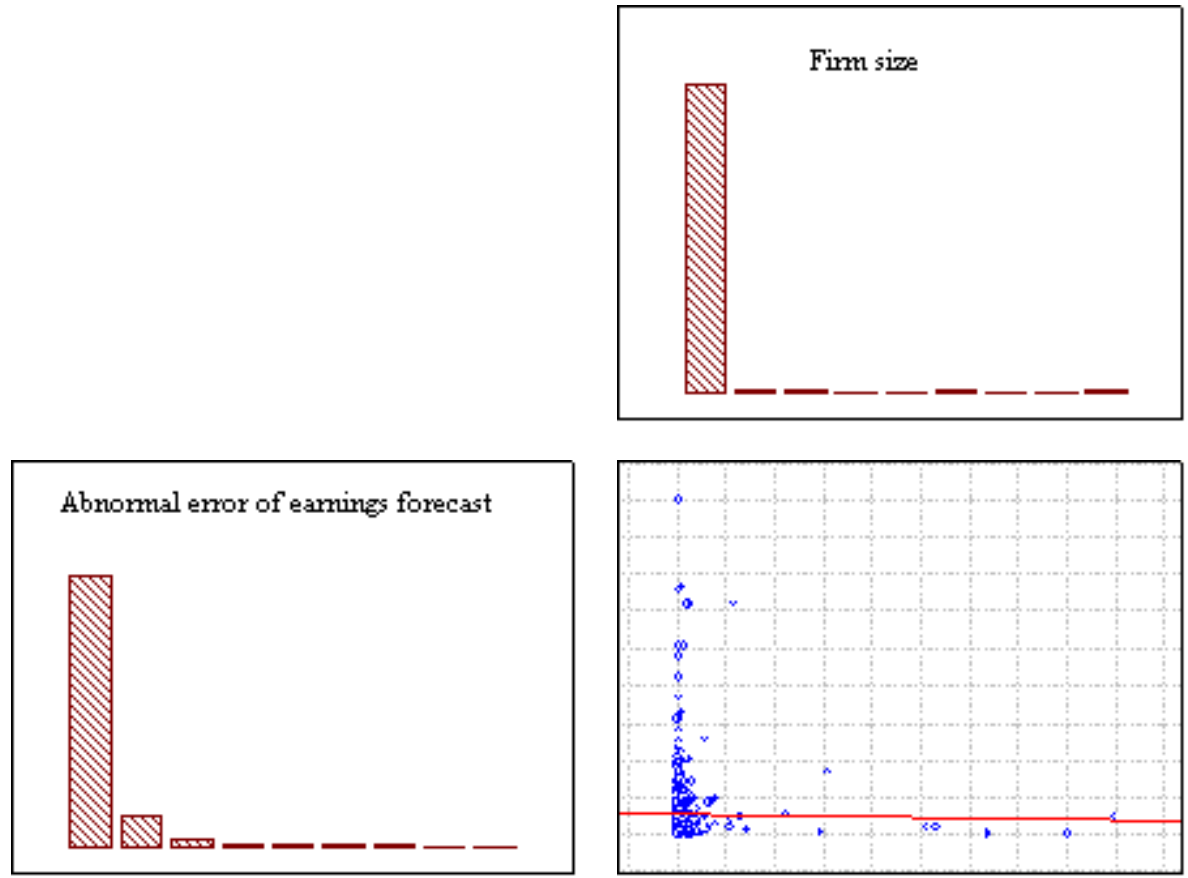

Figure 5: data after normalization

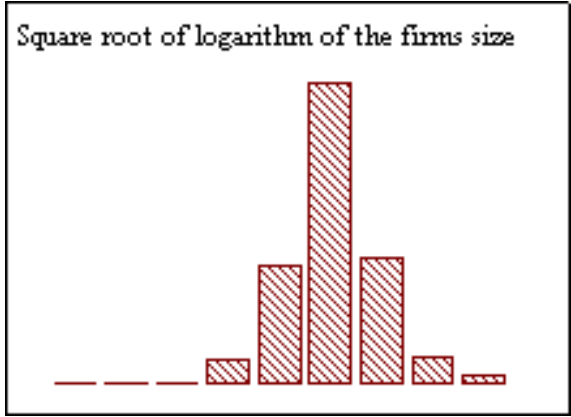

Abnormal error of earnings forecast

The fourth root of the profit's abnomal error
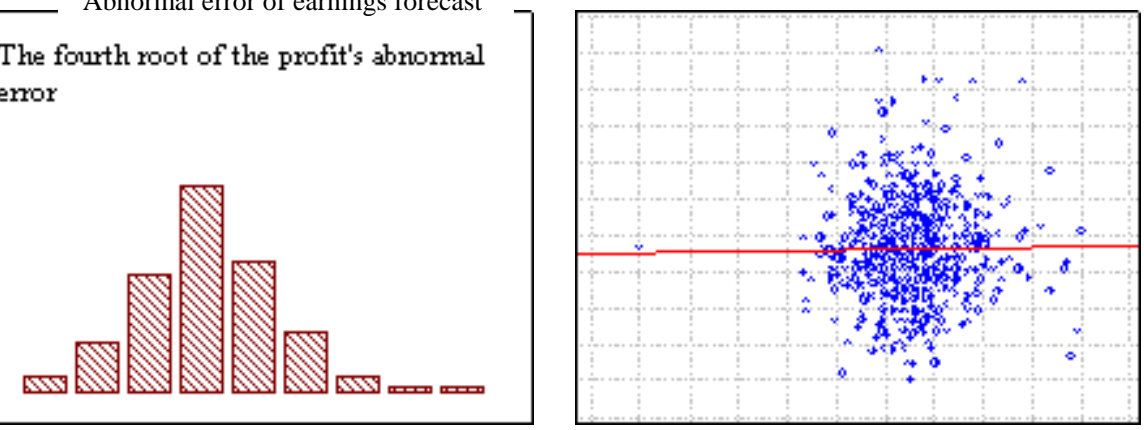

Figure 1. data before normalization

The following figure shows the correlation between the firm size and abnormal error of earnings forecast, after removing irrelevant values.

Figure 6: the relationship between the company's dimension and the abnormal error of profit prediction over the different years 

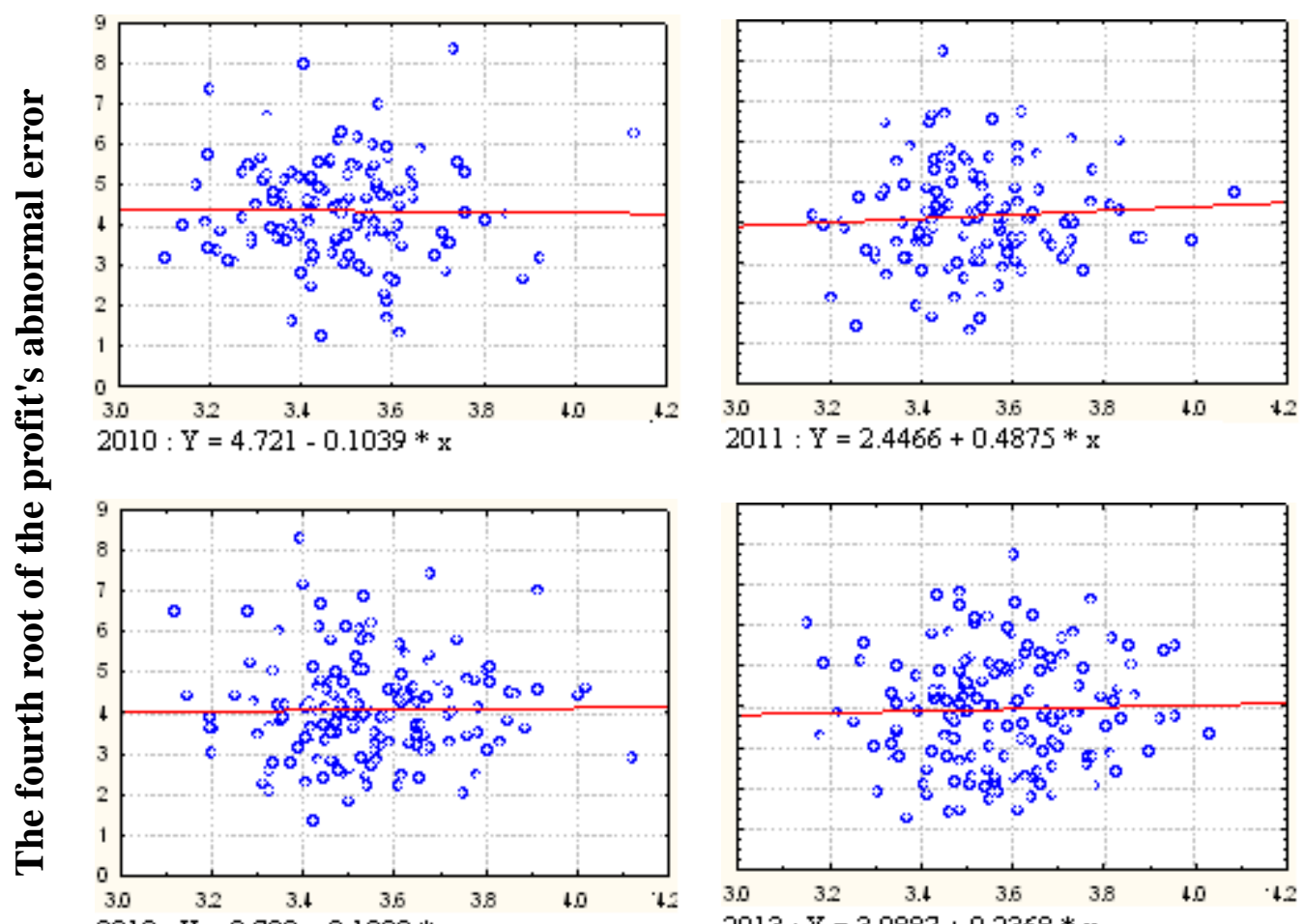

$2011: \mathrm{Y}=2.4466+0.4875 * \mathrm{x}$

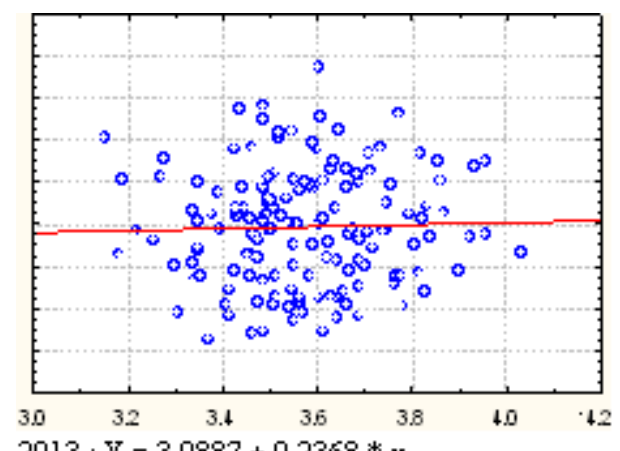

Square root of logarithm of the firm size

Figure 2.

According to the linear regression equation in 2010, the more the firm size, the more the abnormal error of earnings forecast decreases; whereas in years of 2011, 2012 and 2013 the more the firm size, the more the abnormal error of earnings forecast increase too.

Table 4. : the firm size correlation coefficient of the logarithm square root and the fourth root of the earnings abnormal error

\begin{tabular}{ccc}
\hline year & $\begin{array}{r}\text { Firm size correlation coefficient of the logarithm square root } \\
\text { and the fourth root of the earnings abnormal error }\end{array}$ & P-value \\
\hline 2010 & -0.0142 & 0.875 \\
2011 & 0.0644 & 0.481 \\
2012 & 0.0145 & 0.859 \\
2013 & 0.0298 & 0.714 \\
\hline
\end{tabular}


Table 5. Pearson's correlation coefficient

\begin{tabular}{lcc}
\hline Pearson's correlation coefficient & $\begin{array}{c}\text { Log of the square root of firm } \\
\text { size }\end{array}$ & P-value \\
\hline $4^{\text {th }}$ root of abnormal error of earnings & 0.0007 & 0.987 \\
\hline
\end{tabular}

Overall, the firm size has no impact on abnormal error of earnings.

Table 6. Variance analysis for the second hypothesis

\begin{tabular}{ll}
\hline Regression statistics & 0.001 \\
\hline Correlation coefficient & 0.000 \\
\hline Corrected determination coefficient & -0.002 \\
\hline Standard error & 1.273779 \\
\hline No. of observations & 551 \\
\hline
\end{tabular}

Variance analysis:

\begin{tabular}{lccccc}
\hline & f.d & Sum of squares & Average of squares & F-Value & P-value \\
\hline regression & 1 & 0.000455 & 0.000455 & 0.00028 & 0.986652 \\
error & 549 & 890.7596 & 1.622513 & & \\
total & 550 & 890.76 & & & \\
\hline
\end{tabular}

According to the probability value in correlation coefficient, and also the table of variance analysis related to regression line, and its comparison with level of test, it can be said that the null hypothesis, or the hypothesis that "there is no relation between firm size and the extent of abnormal error of earnings" would not be rejected.

Examining the third hypothesis:

To examine the third hypothesis, the test of Pearson's correlation coefficient, and simple linear regression were used after the conversions related to normalization. Also, for a better result, the irrelevant values were removed.

The Table 10 shows the correlation between firm age and abnormal error of earnings forecast. According to regression lines, in 2010 with increase in firm age, the abnormal error of earnings forecast has increased, but in 2011, 2012, and 2013, with increase in firm age, the abnormal error of earnings forecast has decreased. 

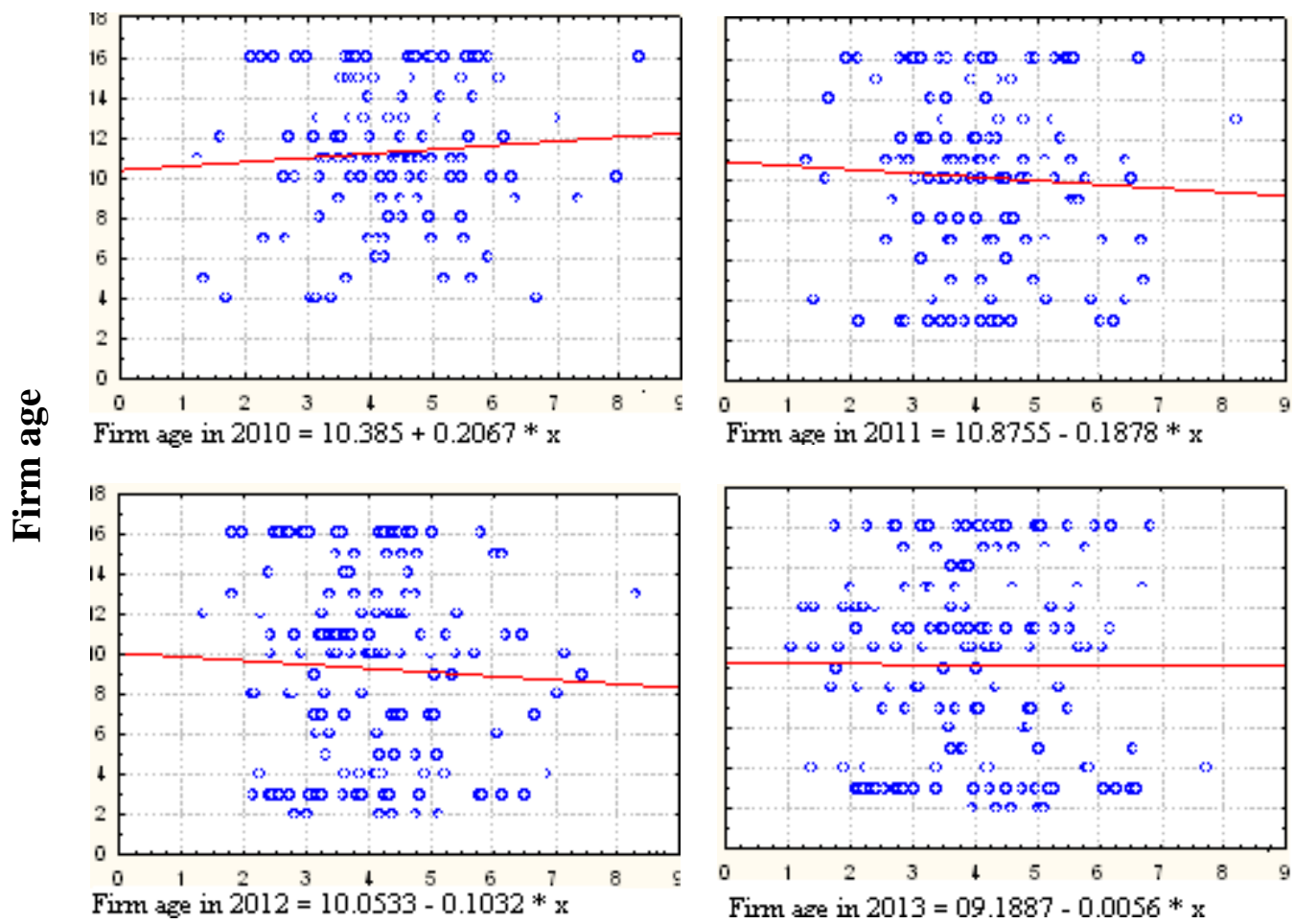

Firm age in $2011=10.8755-0.1878 * x$

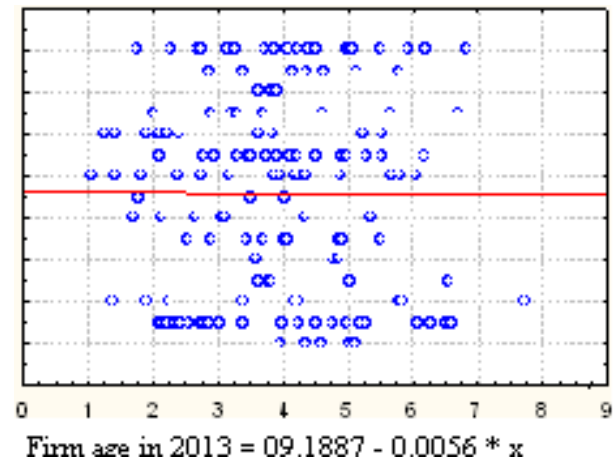

Abnormal error of earnings forecast

Figure 3. The association between firm age and abnormal error of earnings forecast 2010-2013

Table 7. correlation coefficient for logarithm of the square root of firm age, and fourth root of abnormal error of earnings.

\begin{tabular}{ccc}
\hline & Firm age correlation coefficient of the logarithm square & \\
Year & root and the fourth root of the profit's abnormal error & P-value \\
\hline 2010 & -0.0142 & 0.875 \\
2011 & 0.0644 & 0.481 \\
2012 & 0.0145 & 0.859 \\
2013 & 0.0298 & 0.714 \\
\hline
\end{tabular}

According to the above table, in overall the firm age has no impact on abnormal error of earnings forecast. 
Table 8.

\begin{tabular}{lcc}
\hline Pearson's correlation coefficient & The square root of log of firm age & P-value \\
\hline fourth root of abnormal error of earnings & 0.0087 & 0.837 \\
\hline
\end{tabular}

Table 9. variance analysis for the third hypothesis

\begin{tabular}{ll}
\hline Regression statistics & 0.009 \\
Correlation coefficient & 0.000 \\
Corrected determination coefficient & -0.002 \\
Standard error & 1.278 \\
No. of observations & 561 \\
\hline
\end{tabular}

Variance analysis:

\begin{tabular}{lccccc}
\hline & f.d & Sum of squares & Average of squares & F-Value & P-value \\
\hline regression & 1 & 0.069068 & 0.069068 & 0.04232 & 0.837086 \\
error & 559 & 912.3087 & 1.632037 & & \\
total & 560 & 912.3778 & & & \\
\hline
\end{tabular}

According to the probability value in correlation coefficient, and also the table of variance analysis relevant to regression line and its comparison with level of test, it can be said that the null hypothesis or the hypothesis that "there is not relation between the firm age and the extent of abnormal error of earnings forecast" would not be rejected.

Since the hypotheses on the presence of a meaningful relation between firm size and firm age, and the abnormal error of earnings forecast was not confirmed, we want to examine the effect of all three factors together, under the title of GLM model.

\section{General Linear Model (GLM) and the mutual effects of two-factors}

Statistics of General Linear Model:

Correlation coefficient

Square of multiple correlation coefficient

Square of modified multiple correlation coefficient

No. of observations
0.187485

0.035151

0.008595

561 
Variance analysis:

\begin{tabular}{lccccc}
\hline & f.d & Sum of squares & Average of squares & F-Value & P-value \\
\hline model & 15 & 32.07055 & 2.138037 & 1.323663 & 0.182411 \\
error & 545 & 880.3072 & 1.615243 & & \\
total & 560 & 912.3778 & & & \\
\hline
\end{tabular}

Examine of factors:

\begin{tabular}{lccccc}
\hline & $\begin{array}{c}\text { Sum of } \\
\text { squares }\end{array}$ & f.d & $\begin{array}{c}\text { Average of } \\
\text { squares }\end{array}$ & F-statistic & P-value \\
\hline Constant & 0.033603 & 1 & 0.033603 & 0.020804 & 0.885368 \\
Industry type & 3.274268 & 4 & 0.818567 & 0.506776 & 0.730783 \\
Firm size & 2.756227 & 1 & 2.756227 & 1.706386 & 0.192006 \\
Firm age & 2.212053 & 1 & 2.212053 & 1.369487 & 0.242412 \\
Industry type*firm size & 3.676743 & 4 & 0.919186 & 0.56907 & 0.685196 \\
Industry type*firm age & 1.602081 & 4 & 0.40052 & 0.247963 & 0.910891 \\
Firm size*firm age & 2.257542 & 1 & 2.257542 & 1.397649 & 0.237633 \\
\hline
\end{tabular}

General Linear Models are the models similar to regression models. In these models, in addition to independent quantitative variables, classified variables can be used too. In this research, we examined a General Linear Model with three variables (two quantitative and one qualitative factor) and mutual effects of every two factors. To analyze these models, we used a method entitled covariance analysis. According to probability value, a model with above variables is not a good model, and a model with less factors should be employed. The difference between determination coefficient and modified determination coefficient is a proof for this claim.

General Linear Model (GLM) with two-factor mutual effects after removing unnecessary factors

\begin{tabular}{ll}
\hline Statistics of General Linear Model & \\
\hline Correlation coefficient & 0.170275 \\
Square of multiple correlation coefficient & 0.028994 \\
Square of modified multiple correlation coefficient & 0.018477 \\
Number of observations & 561 \\
\hline
\end{tabular}

Covariance analysis:

\begin{tabular}{lccccc}
\hline & Sum of squares & f.d & Average of squares & F-Statistic & P-value \\
\hline Model & 26.45308 & 7 & 3.779011 & 2.363149 & 0.021917 \\
Error & 885.9247 & 554 & 1.599142 & & \\
total & 912.3778 & 561 & & & \\
\hline
\end{tabular}




\section{Examine of factors:}

\begin{tabular}{lccccc}
\hline & $\begin{array}{c}\text { Sum of } \\
\text { squares }\end{array}$ & d.f & $\begin{array}{c}\text { Average of } \\
\text { squares }\end{array}$ & F-Statistic & P-value \\
\hline Firm size & 1474.358 & 1 & 1474.358 & 921.9682 & 0.000 \\
Firm age & 27.88639 & 1 & 27.88639 & 17.43834 & 0.000 \\
Industry type*firm age & 24.37733 & 4 & 6.094332 & 3.811001 & 0.005 \\
Firm size*firm age & 27.73935 & 1 & 27.73935 & 17.34639 & 0.000 \\
\hline
\end{tabular}

After removing unnecessary variables and constant value in the previous model, the following model would be resulted:

$\mathrm{Y}=\infty_{0}+\infty_{1} x_{1}+\infty_{3}\left(x_{2} x_{2}\right)+\infty_{4}\left(x_{1} x_{2}\right)$

Where:

$x_{1}=$ the firm size;

$x_{2}=$ the firm age;

$\left(x_{1} x_{2}\right)=$ the firm size $\times$ firm age; and

$\left(x_{2} x_{0}\right)$ is industry type $\times$ firm age.

According to the model, the firm size and firm age factors, which are present in the model independently and simultaneously, have impact on abnormal error of earnings, but industry type exert its effect just through the firm age.

\section{Conclusion}

Summary of the results of hypothesis examinations is shown in bellow: 


\begin{tabular}{|l|l|l|l|l|}
\hline Hypotheses & year & correlation & $\begin{array}{l}\text { Meaningfulness } \\
\text { relation }\end{array}$ \\
\hline The first hypothesis & confirmed \\
\hline $\begin{array}{l}\text { Industry type and abnormal error of } \\
\text { earnings forecast }\end{array}$ & - & - & Not confirmed \\
\hline The second hypothesis & $\begin{array}{l}\text { Firm size and abnormal error of earnings } \\
\text { forecast }\end{array}$ & - & - & Not confirmed \\
\hline $\begin{array}{l}\text { Firm size and abnormal error of earnings } \\
\text { forecast }\end{array}$ & 2010 & reversed \\
\hline $\begin{array}{l}\text { Firm size and abnormal error of earnings } \\
\text { forecast }\end{array}$ & 2011 & direct & Not confirmed \\
\hline $\begin{array}{l}\text { Firm size and abnormal error of earnings } \\
\text { forecast }\end{array}$ & 2012 & direct & Not confirmed \\
\hline $\begin{array}{l}\text { Firm size and abnormal error of earnings } \\
\text { forecast }\end{array}$ & 2013 & direct & Not confirmed \\
\hline The third hypothesis & & ret & Not confirmed \\
\hline $\begin{array}{l}\text { Firm age and abnormal error of earnings } \\
\text { forecast }\end{array}$ & - & - & Not confirmed \\
\hline $\begin{array}{l}\text { Firm age and abnormal error of earnings } \\
\text { forecast }\end{array}$ & 2010 & direct \\
\hline $\begin{array}{l}\text { Firm age and abnormal error of earnings } \\
\text { forecast }\end{array}$ & 2011 & reversed \\
\hline $\begin{array}{l}\text { Firm age and abnormal error of earnings } \\
\text { forecast }\end{array}$ & 2012 & reversed \\
\hline $\begin{array}{l}\text { Firm age and abnormal error of earnings } \\
\text { forecast }\end{array}$ & 2013 & reversed & Not confirmed \\
\hline
\end{tabular}

The results of this research indicate there is a meaningful relationship between the type of industry, and the effective factors in abnormal error of earnings forecast. The mining, chemical materials, petrochemical and pharmaceutical industries have high abnormal error of earnings forecast, while metal industries, agriculture, and animal husbandry have low abnormal error of earnings forecast. Also we find in this research that there is a meaningful relation between the firm size, and the firm age in stock exchange.

\section{References}

Bahramian.M. (2007). Inaccuracy of forecasting earnings of the companies in the new issuing of shares and increase of capital, Master thesis, Allame Tabatabaei University.

Ball.R.J., \& Brown. (1968). An empirical evaluation of accounting income numbers. Journal of accounting research, 103-26. 


\section{Macrothink}

Asian Journal of Finance \& Accounting ISSN 1946-052X 2014, Vol. 6, No. 2

Beaver.W.H. (1968). The information content of annual earnings announcement. Journal of accounting research, 67-92.

H.Khaleghi Moghaddam. (1999). The Accuracy of profit forecasts of firms, PhD dissertation, Tehran University.

J.M.Patell. (1976). Corporate Forecasts of earnings per share and stock price behavior: Empirical Tests. Journal of accounting research, 246-76.

Jahankhani.A., \& Saffarian.A. (2003). The stock market reaction to the announcement estimated earnings per share in TSE, Financial researches, No. 16.

M.Firth. (1998). IPO profit forecasts and their role in signaling firm value and explaining post-listing returns. Applied financial economics, 29-39.

R.Lonkain, \& M.Firth. (2005). The accuracy of IPO earning forecasts in Thailand and their relationships with stock market valuation. Accounting and business research, 256-69

W.Ruland. (1978). The Accuracy of forecasts by management and financial analysts. The accounting review, 2(2), 440. 